\title{
TIMBER ANTI-SEISMIC DEVICES IN HISTORICAL ARCHITECTURE IN THE MEDITERRANEAN AREA
}

\author{
TIZIANA CAMPISI ${ }^{1} \&$ MANFREDI SAELI $^{1,2}$ \\ ${ }^{1}$ Department of Architecture (DARCH), Polytechnic School, University of Palermo, Italy. \\ ${ }^{2}$ Department of Materials Engineering and Ceramics/CICECO, University of Aveiro, Portugal.
}

\begin{abstract}
This work investigates the exploitation of a historical timber device used as masonry reinforcement in seismic prevention in the Mediterranean area. Such a technology is realized by means of a three-dimensional timber frame embedded in stone masonry in order to bind together the various structural parts, and contribute to the overall seismic resistance. Very often, such a constructive principle was extended not only to the weakest parts but to the whole building, creating new structural configurations that were able to absorb the effects of seismic ground motions. From Roman times (opus craticium), this system spread all across the Mediterranean area becoming common during the eighteenth century in Italy (Bourbon casa baraccata), in Portugal (Pombaline gaiola), in Turkey (hımış), etc. However, examples of timber devices and frameworks may be found almost worldwide: in the continental northern Europe, including those countries that are usually not subjected to earthquakes, as well as in Central Asia or in Japan, to America and North Africa. A large number of examples are reported to show how some traditional technologies, along with the suboptimal rules of the art, made a robust construction possible. Furthermore, by means of philological criterion and detailed analysis of seismic vulnerability improvement, the knowledge of such a system may allow developing novel designs and specific preservation works that could ensure the structural safety of historical constructions without modifying their main structural configuration. From such a perspective, this study examines the aspects of using diffused timber frameworks with masonry infill that go beyond anti-seismic technology, describes the common constructive features and helps develop guidelines for preservation of such systems.

Keywords: construction materials, constructive technology, historical architecture, masonry, seismic reinforcement, timber frame, wood.
\end{abstract}

\section{INTRODUCTION}

Although historical architecture frequently shows a formal and stylistic unity, its various constitutive parts subtend a variety of additions and subtractions of matter or structural portions, superimpositions, modifications, etc. That is certainly one of the most fascinating characteristics that make every building unique. These modifications have generally occurred during centuries and for many reasons: sometimes they are the result of simple reconfigurations or renovations and at other times of undisputed necessity. Very often, as well as we ordinarily do in the present days, buildings were reformed to conform to the most recent architectural and artistic designs in vogue. Distribution of inner spaces was made to adapt to the most modern and changing living conditions, and structures were improved and modernized with the most advanced equipment and technological evolutions. On the other side, sometimes, modifications occurred in order to reconstruct parts that had collapsed following some disastrous events such as earthquakes [1]. Thus, the final building looked formally unique, in line with the stylistic standards of the time, and equipped with the most novel advances; however, such modifications inevitably created new structural entities. Unfortunately, earthquakes are disastrous events that frequently lead to buildings' reconfiguration or reconstruction. In every century the extent of damages to towns has been chronicled. The violence of these events has commonly been the result of soil and geological characteristics 
as well as intrinsic properties of the materials and structures. Increased building height and density have commonly been factors that have aggravated the risk of building collapse [2].

As it frequently happens in any situation of emergency, the technologies used in a specific place are immediately verified in relation to the expected structural performance. Such a comparison between events, methods and effects inevitably leads to a heated debate on the most appropriate way to exploit the knowledge of the building, on the local rules of the building art along with strengthening the safety demands, in order to provide security to the people living and working in the urban environments, the current historical centres. In many cases, it is commonly reported how innovations that have effectively brought some improvisations to the already known technical knowledge are only a few. On the other hand, the surviving and less damaged structures provided important information on the most resistant 'anti-seismic' systems. In any case, preference was given to the local constructive rules that were far more reassuring. On the contrary, the reconstruction dared with experimentations that were considered highly innovative, introducing technological developments to be associated to the oldest and most traditional constructive methodologies [3, 4].

Among the number of constructive technologies that best performed in the event of earthquakes, those structures using wood, along with proper timber frameworks, generally survived disastrous events or, at least, showed minor damages, compared to stonework. As a consequence, exploiting the elastic behaviour of wood, as compared to stone and masonry, led to a sort of compromise between tradition and immediate emergency.

Furthermore, reconstructions and rehabilitations of damaged buildings were made faster and easier thanks to wood versatility. Very often, indeed, we can observe many timber devices (frameworks, chains, tie-beams, supports, shelves, etc.) used as masonry reinforcement in seismic damage prevention of historical architecture. Such a constructive system was usually realized by means of the insertion of a three-dimensional timber frame embedded in stone masonry in order to bind together its various parts and contribute to the overall structural and seismic resistance. In many 'restorations' or reconstructions, such a constructive principle was extended to the whole building, generating completely novel structural configurations that were able to absorb the effects of seismic ground motions.

Anyway, such a common exploitation of wood and timber framework fell within a much larger and general debate on efficient constructive technologies and anti-seismic devices. Aligned empty spaces or heavy projections (stone balconies or massive cornices) should be avoided on façades and openings (doors, windows) should be avoided close to bearing walls. Again, pushing structures (vaults) should not be used on the upper floors or roofs and, if present, they should be stabilized by inserting some metallic or wooden chains. Just to mention some of the rules of the art of good and proper building practice $[1,5,6]$.

In the following sections, many notable examples that may be found in the Mediterranean area are reported, focusing on the most famous construction technologies.

\section{THE ROMAN TECHNOLOGY}

To begin with, some eminent examples of constructive technologies that contributed to the diffusion of the timber frame masonry in construction are mentioned. Particularly important is the treatise De architectura written by the Roman military engineer Vitruvius as a real guide for building projects [7]. Such a work, as one of the few treatises on architecture to survive from antiquity, made scholars attain good knowledge of the development of constructive technologies in Roman times, associated with the inspection of the myriad of archaeological remains. Among the first constructive experiences, the opus craticium (Fig. 1) 


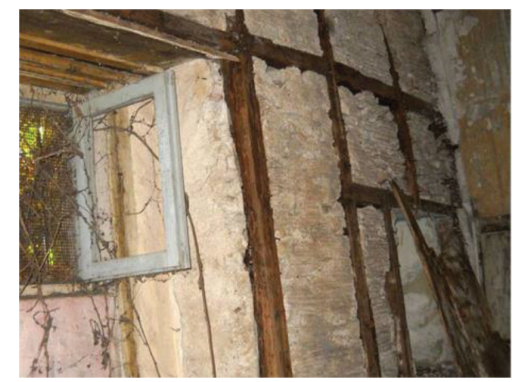

Figure 1: Opus craticium.

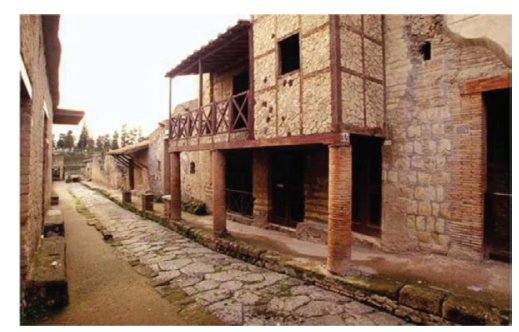

Figure 2: House of Frameworks in Herculaneum.

was frequently used in new constructions as well as in reconstructions following earthquakes. However, the paries craticius was considered a point of weakness by Vitruvius [7] as it was highly flammable; nevertheless, it was commonly used due to its low cost and fast speed of execution. This typology is also called cratis parietum by Pliny the Elder [8] and, later, craticiis podis by Andrea Palladio [9]. All such terms are derived from the Latin word crates that indicates a wall framework made of reeds or brushwood fastened tightly by means of cordage, which acts as a sort of armour within the stone masonry [10].

Due to the high perishability of wood, nowadays it is difficult to find traces of such a technology. Some remaining evidences are the walls of the western rooms of the House of Giulio Polibio's atrium, a partition wall of the secondary vestibule of the House of the Theatrical Paints along with all the walls of the House of Frameworks in Herculaneum (Fig. 2). In the last mentioned one, the plaster of an upper floor room's wall is also well preserved thanks to Vitruvius prescriptions on how to avoid cracks: an inner layer of clay mortar is followed by a second one of horizontal reeds fastened by nails, which follow another stratum of clay mortar and again reeds, this time organized perpendicularly.

Such a technology allowed to build bearing walls as well as light partitions thanks to the timber framework (graticius) made of vertical columns (arrectaria), horizontal beams (transversaria) and diagonal cross-bracing elements connected by means of various joints: the common 'mortise and tenon' or in-thickness wooden pins. The real supporting structures are obviously the columns and the beams erected on a basement made of stone or brick (sometimes it was the whole ground level), with the main function of protecting wood from the ground humidity thereby providing long-lasting durability. At every attic level, a long horizontal sleeper-beam was located in order to better distribute the vertical loads and make the usage of shorter vertical columns possible: usually, their length corresponded to the entire free floor height even if it was not that easy to find long and straight tree trunks. Furthermore, the construction required a great amount of wood. Horizontal and diagonal elements were 
used to stiffen the whole structure making it crushproof in addition to distributing the loads in a suboptimal way. Doors and windows were built at the same time of the walls leaving the voids where needed. Once the work of carpentry was completed, the timber framework - that was usually left in sight making a particular effect of such a structure - was filled in with various types of materials: masonry with unshaped or regular stones (opus incertum, opus quadratum), bricks, clay mixed with straw or even simple plastered creeds in the poorest constructions. To preserve the craticii from crumbling, they were usually covered by three or four layers of mortar and sand (opus tectorium), increasingly thinner and more fluid: the finishing, called opus albarium, was made of lime and gypsum resulting in a highly bright coating $[11,12]$.

\section{THE EIGHTEENTH CENTURY FRAMED-REINFORCED HOUSE: ITALIAN CASA BARACCATA}

The Middle Ages did not produce significant examples of timber-frame constructions, apart from few buildings: the stone technology was usually preferred as it was considered more solid, especially for military and defensive purposes. Only in the sixteenth century, Pirro Ligorio attempted a scientific approach to the anti-seismic house that further led to the exploitation of the timber framework system. From the accelerated development of the scientific theories, scholars and enlightened monarchs or governors tried to understand how and why buildings collapse, or did not, after an earthquake, arriving at three possible options: preserve what has remained standing, reconstruct in modernity or abandon the ruins [13].

The Bourbon Reign, in Centre-Southern Italy and Sicily, was highly fecund in anti-seismic construction theory and realizations. As it usually happened, the occurrence of cyclic earthquakes created circumstances to study the causes of building collapse. As a consequence, a number of experimentations were attempted within the scientific/technical environments, fighting against the inertia of maintaining the old and well-known constructive practices. In such a scenario, the timber constructive system has prevailed and the framed-reinforced house, the so-called casa baraccata, took birth [14].

Following one of the most disruptive earthquakes that occurred in Calabria in 1783 (Magnitude $=6.9$ ), the Bourbon government released a normative, the first of its kind, that permitted the reconstruction following some fundamental principles: beyond the infrastructural system - large streets (10-13 m) and squares for markets, designed to accommodate in the case of a disaster the surrounding population - the collapsed structures must be rebuilt using a masonry «(...) with an inner frame of large trusses (...) fasten by other transversal beams (...)» [15]. Such a structural typology was designed by the Spanish military engineer Francesco La Vega who was inspired by the Roman houses of Herculaneum and Pompeii, whose La Vega was in charge of the excavations.

Also Giovanni Vivenzio, a university professor and member of the Bourbon court, after having noted that the mixed masonry/wood structures had showed the best performance during the 1783 earthquake designed his prototype house made of wood (Figs 3 and 4) [16]. More particularly, he studied the Palace of the Count of Nocera in Filogaso, which was the only building in the town that remained fixed, and observed that the main cause of such a diffused devastation was the common usage of poor or recycled construction materials. In his project, the main structure was fastened by a robust timber framework: each frame was double in size and reinforced by transversal buttresses and diagonal elements; the cavities among the frames were filled in with stones or concrete. The building he proposed was not a proper timber framework structure but a mixed constructive solution whose principles were structural unity, diagonal wind-bracing and symmetry. 


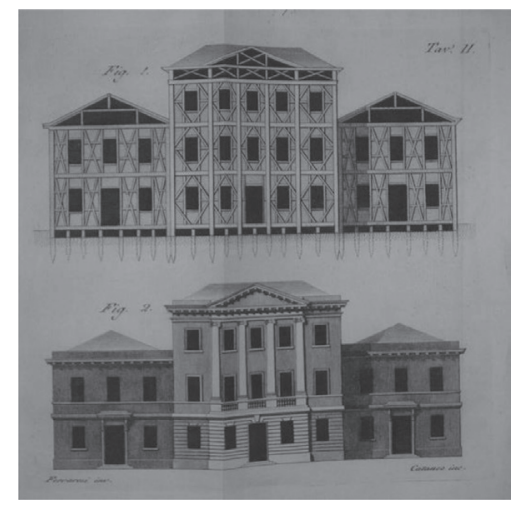

Figure 3: G. Vivenzio, casa baraccata: section and façade.

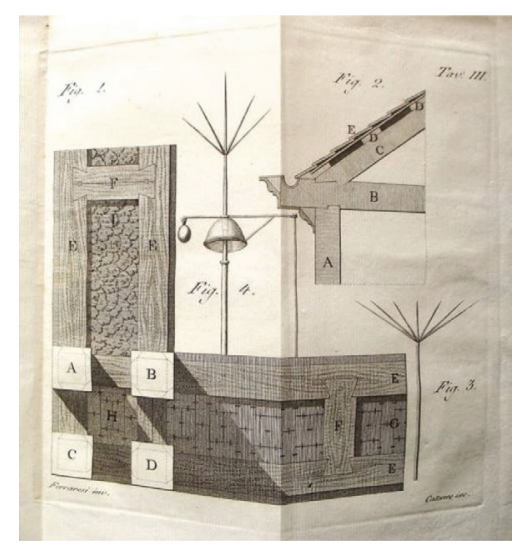

Figure 4: Wall with timber frame and masonry infill, details of a roof.

Indeed, thanks to its elasticity, wood could be bent without virtually breaking, thus it was ideal to be used to resist seismic waves. Wood was at the basis of the framed-reinforced house representing a good improvement towards seismic safety. Furthermore, those kind of buildings could be erected faster and easier, compared to the ones made of stone, and were much lighter and, thus, less dangerous in case of ruin. Finally, wood exhibited another positive advantage: the structural elements were interconnected creating a box system, more homogeneous and continuous (Fig. 5) [17].

\section{THE SICILIAN EXPERIENCE}

Also, Sicily experienced a widespread exploitation of wooden structures as seismic reinforcement material. Again, experimentations and innovations came out of observations of the post-seism remaining buildings, i.e. earthquakes in Eastern Sicily in $1693(\mathrm{M}=7.4)$ or in Palermo in $1726(\mathrm{M}=6)$. Reconstruction was based on retro-fitting or structural consolidation using the traditional rules of the art. However, the local technical knowledge based on ephemeral decorative apparatus, which exploited light wooden framework, was also successfully applied. Indeed, wood represented a common resource, easy and fast to assemble or dismantle, light, reusable and versatile. To summarize, it had all those characteristics useful 


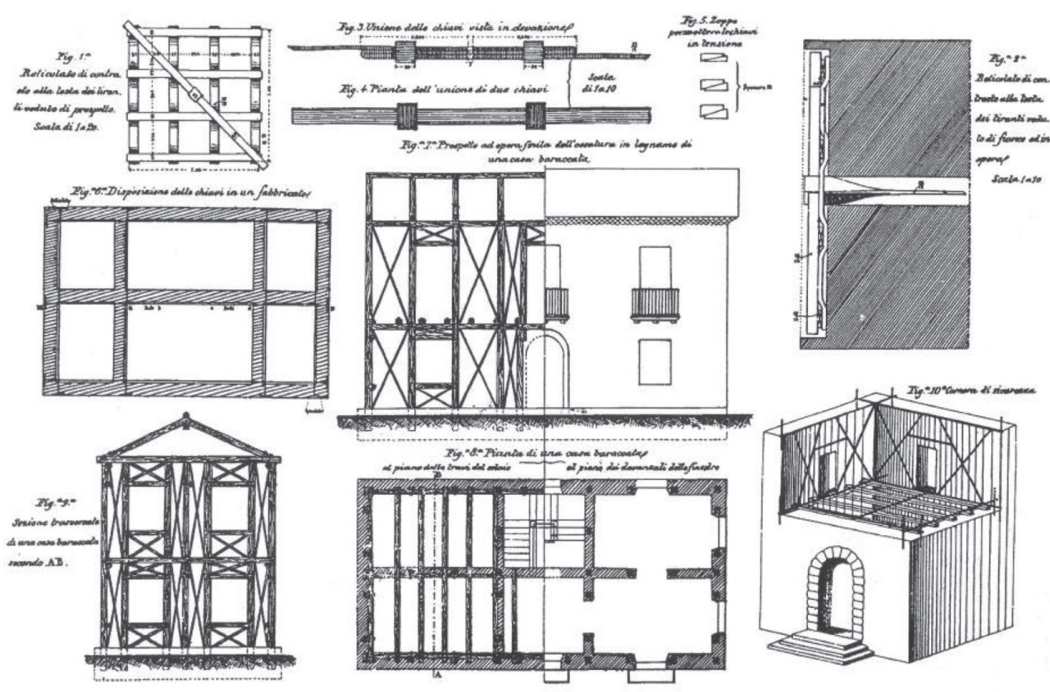

Figure 5: Studies of timber framework for seismic reinforcement (source: [17]).

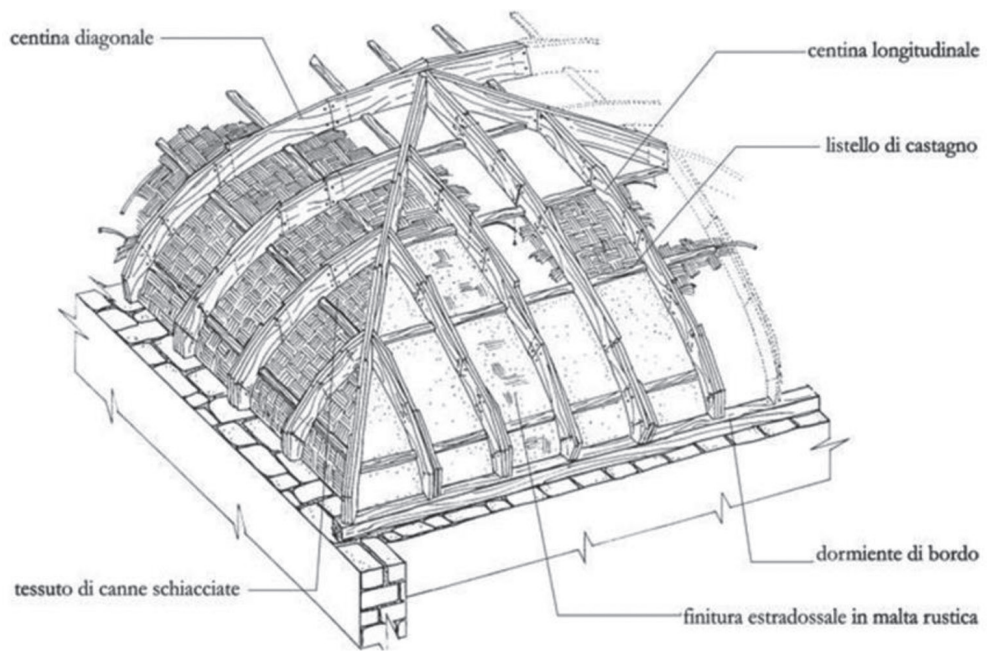

Figure 6: Structure (extrados) of a typical Sicilian false vault.

for solid structural purposes [18]. An interesting example is represented by the technology used to build the 'false vaults' (Fig. 6). Decorative but without any structural functions they are characterized by a wooden framework, reproducing the desired geometry completed at the intrados by a fabric of reeds that is plastered and, eventually, decorated by frescoes or stuccoes $[19,20]$. The accomplished high-tensile strength of wood, along with its elasticity, resulted in it being used as chain in post-earthquake reconstructions for improving structural safety. The adoption of wooden chains as reinforcing elements had indeed a long local tradi- 


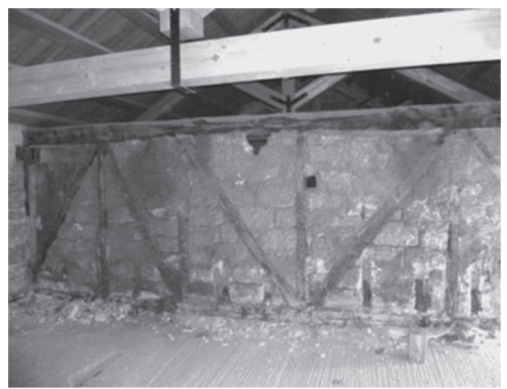

Figure 7: Wooden partition wall where spaces are filled with reed.

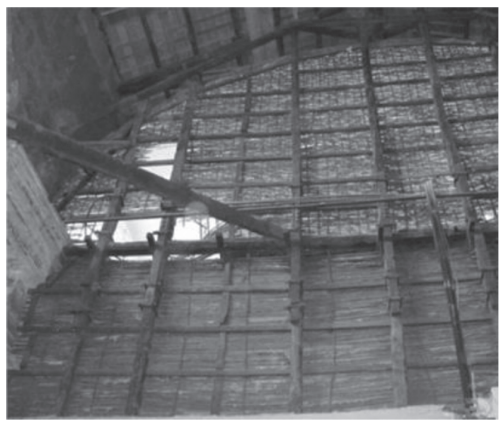

Figure 8: Wooden partition wall where thin ashlars are used.

tion. Wood was also used for various structural elements such as in ceilings and light partition walls (Figs 7 and 8). The former, usually constituted a self-supporting structural system: flat and vaulted ceilings were frequently connected to the beams on the upper floor or to the chains of the trusses $[1,2]$.

\section{THE EIGHTEENTH CENTURY PORTUGUESE POMBALINE SYSTEM: THE GAIOLA}

Another famous timber frame constructive system is the Pombaline gaiola, prescribed in Lisbon after the great earthquake of $1755(\mathrm{M}=8.5-9)$ that, in combination with subsequent fires and a tsunami, almost totally destroyed the city and the surrounding areas. Its designer was the First Marquis of Pombal, Prime Minister to Joseph I in 1750-1777, who imposed strict conditions on rebuilding the lower city. Thanks to the high technological level attained after the previous earthquakes (i.e. 1531, 1551) and the military experience in building on incoherent or river grounds, along with long-lasting expertise in naval constructions, an excellent level of knowledge was reached [21]. The main problems that have been observed in constructions in Lisbon were the basements and real stone vaults present at the upper levels, and the walls made of limestone supported by a light and open wooden structure, not in a closed boxed system.

Beyond a series of urban, environmental and architectural prescriptions, the most substantial object of the edict was to adopt strict structural and technological construction methods. Buildings' masonry had to be reinforced by an inner wooden symmetrical cage, the gaiola (Figs 9-11), aimed at distributing seismic load, and enforced by inter-terrace walls built higher than roof timbers in order to reduce fire propagation through the whole construction 


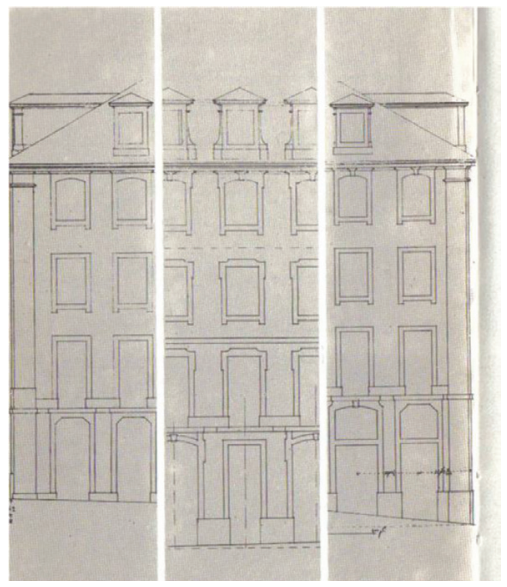

Figure 9: Study of a façade in a Pombaline building in the neighbourhood of Baixa.

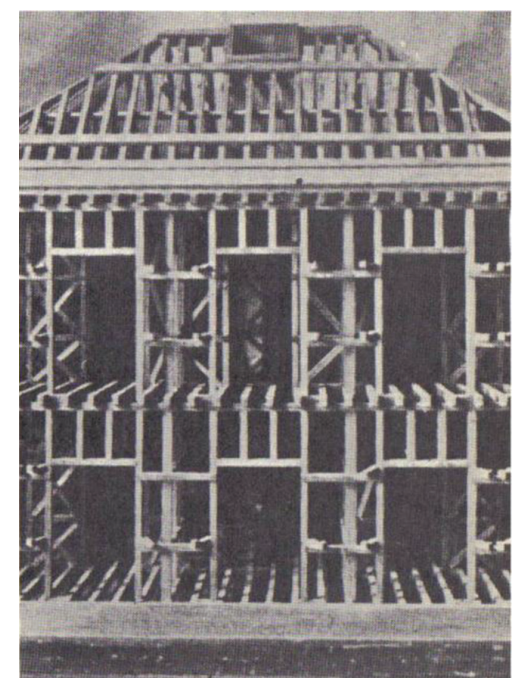

Figure 10: Structural scheme of a Pombaline building, using the gaiola system.

or to the adjacent ones. It is notable that in the case of an earthquake, the timber framework might have supported the slabs and the roof if the stone walls were ruined down, thanks to its structural independency. The timber framework elasticity granted to the cage an enormous ultimate resistance, tested in an architectural scale simulating an earthquake vibration by having troops march around it [22]. Moreover, such a frame was highly flexible thanks to a system of columns, beams, architraves and rafters perfectly jointed by means of dowels, tenons and connections made of wood themselves and, finally, embedded into the walls $[23,24]$.

Nowadays, it is still possible to see such a constructive system, highly common in the Pombaline city (neighbourhood of Baixa). In the most recent works of preservation and refurbishment it is usually put in sight with the indirect consequence of calling into question its primitive structural function (Figs 12 and 13). 


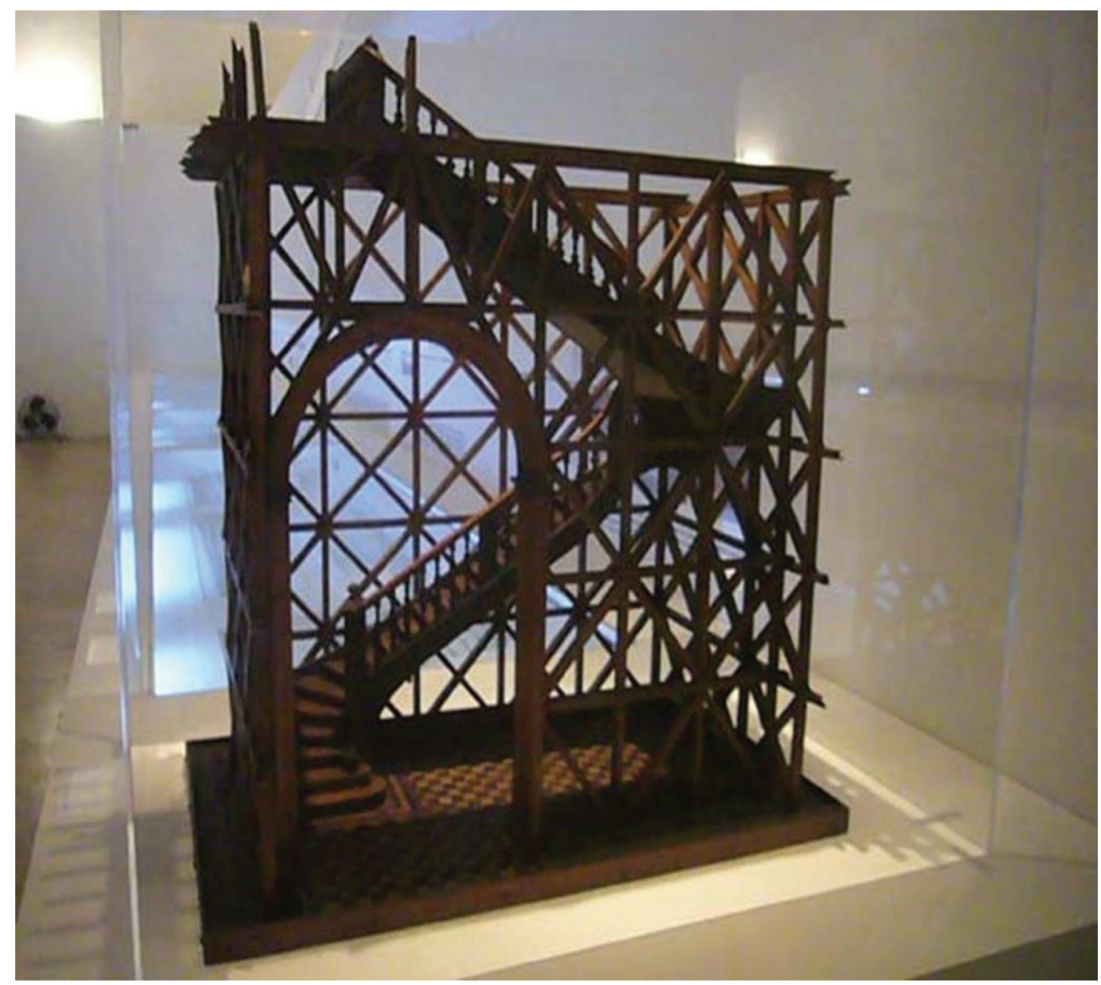

Figure 11: Reconstruction of a Pombaline gaiola (Instituto Superior Técnico de Lisboa).
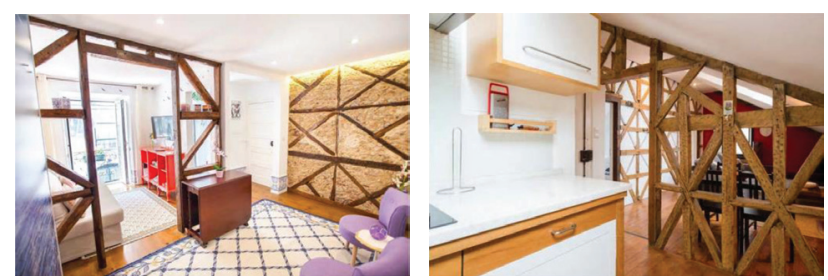

Figures 12 and 13: Works of preservation and refurbishment in a Lisbon apartment.

\section{EAST MEDITERRANEAN EXPERIENCE: TURKISH HIMIS}

Similar solutions may be found in the Middle East, particularly in Turkey, where timber framework with brick infill has been documented since the eighth century [25].

During its history, such a region experienced frequent seismic events. Following some recent earthquakes (Erzincan earthquake of $1939(\mathrm{M}=7.9)$, Marmara earthquake $(\mathrm{M}=7.6)$ and Düzce earthquake $(\mathrm{M}=7.2)$ both in 1999) it was surprisingly observed that the less damaged houses, and often the only ones standing, were the traditional vernacular hımıs, rather than the contemporary reinforced concrete constructions (Fig. 14). Differently from what has been analysed so far, hımış technology spread rapidly from the seventeenth century for its structural performance under seismic loading not as a scientific and conscious search for a seismically resistant building form [26]. 


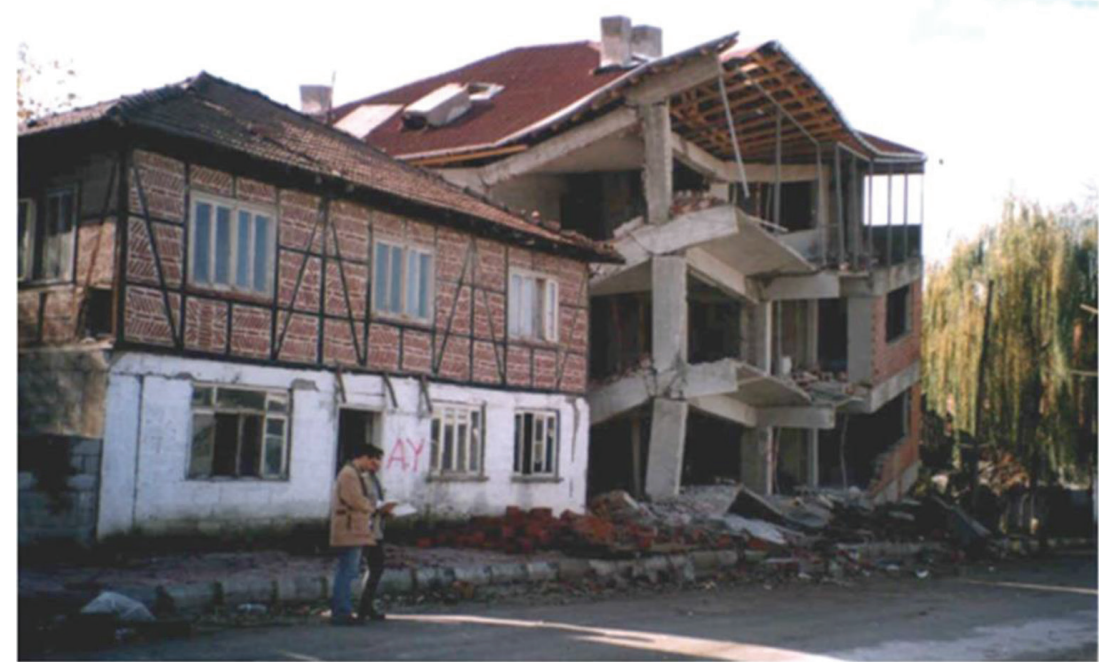

Figure 14: A hımışstanding next to a destroyed contemporary reinforced concrete construction after the Düzce earthquake in 1999 (yoremizden.com).

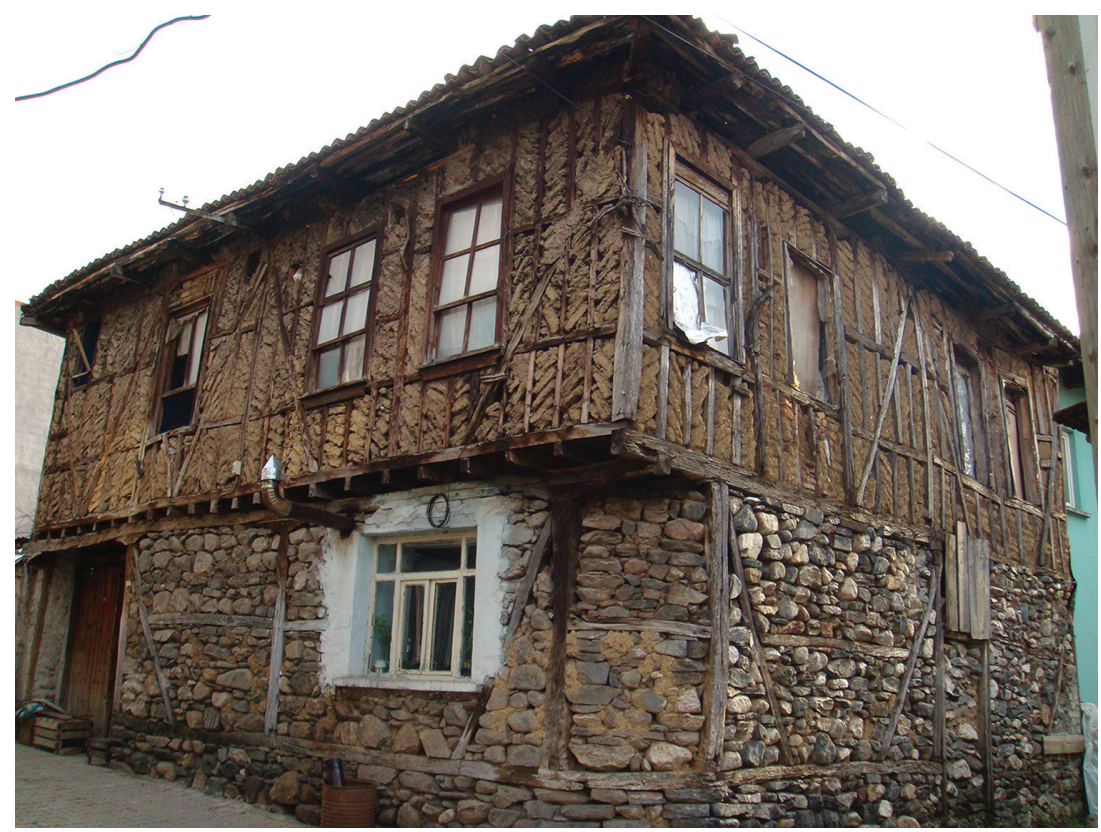

Figure 15: Turkish traditional house with the ground floor made of stone with some wood insertions, and the upper floor made exploiting the hımış system.

Turkish traditional architecture is characterized by a ground floor made of stone-bearing walls, that are often laced with horizontal runner beams, and the upper floors made of an infill construction: a timber framework and a masonry infill, the hımış, precisely. Such a change in materials and constructive technology, made the upper floor construction lighter, allowing the 


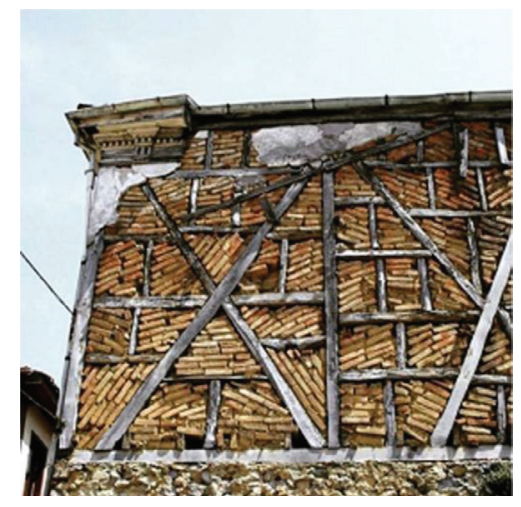

Figure 16: Detail of an upper floor hımıs with brick filling between timber frames.

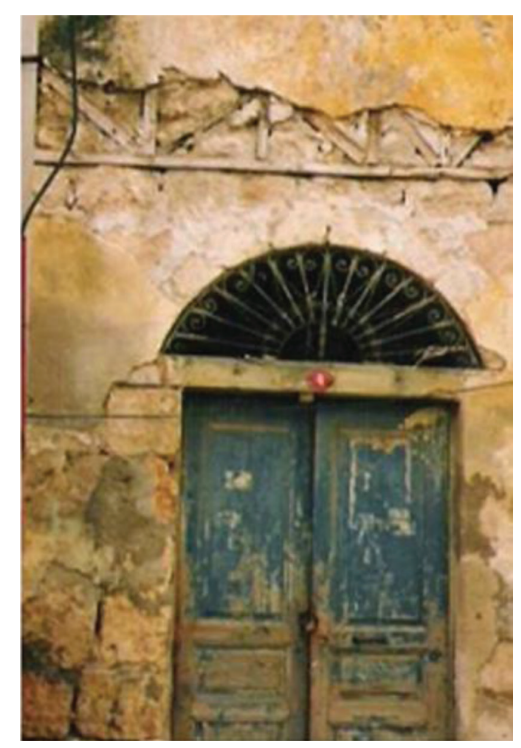

Figure 17: Fallen lime plaster put in sight the hımış system of the upper floor.

typical bays and jetties that overhang the streets (Fig. 15) [27, 28]. The filling is generally made of mud bricks (Fig. 16) between wooden frames created by sewing and sequins. The walls of these constructions are traditionally plastered with lime, linen or earth plaster both internally and externally (Fig. 17). In the various regions, it is possible to observe slight differences, especially in terms of infill/cladding materials/types. On the other hand, the general configuration and design principles are generally reported over a highly vast geographic area, from the inner Anatolia to the Balkans and Greece.

\section{DISCUSSION AND CONCLUSIONS}

In this work the exploitation of a constructive technology intended for seismic reinforcement that is realized by means of a three-dimensional timber framework embedded in stone masonry has been analysed. More particularly, many examples of such a technology focussing on the Mediterranean area have been reported and discussed. 
Post-disaster studies have usually reported a good seismic performance of timber frame structures in a diffused devastation, allowing an accurate analysis of local constructive technologies and materials. Those observations are essential to choose the best technology for a specific place that is characterized by local materials and uses. Usually, traditional native or vernacular architecture shows mixed structural configurations. Moreover, supported by archival documents and studies on the old works of restoration, it is possible to find a larger number of examples that may be often hidden to inexperienced eyes. Thus, also the most aulic buildings might show a mixed structure: theatres, aristocrat palaces, monasteries, churches, etc., that prove the capillary exploitation of such a technology, with modifications and originalities linked to specific cases or areas. In many Mediterranean countries, for centuries the timber frame embedded in stone masonry has been largely exploited as a typical constructive lexicon in the building environment.

In such a way, the goal is to preserve the existing timber structures and to reconstruct the ruined ones, if possible, as structural anti-seismic devices. Actually, timber frame limits the collapse of the masonry by absorbing the seismic loads, either as a chain or wind-bracing, binding the bearing walls and making their overturning less probable. In many cases, a great amount of the energy is dissipated by friction between the pieces of infill material [29]. Moreover, a timber frame, as compared to stone, is lighter and reduces the over-loads on its supports, is more deformable and less rigid thanks to the inevitable and suboptimal scrolling at the nodes and joints. Nowadays, the present restoration guidelines suggest the preservation of the original wooden frames, rather than their demolition, if their seismic performance is sufficiently reliable. In the case of reconstruction, such a system could be philologically reproduced if attested by documentary sources and if its seismic performance satisfies the construction regulations. The present usage of a timber frame as a structural anti-seismic device, may also consider some requirement of internal wellness, thermal-acoustic insulation, fire security and durability. The relation between the old stratified masonries and the new timber frames should coherently fit the expected structural, technological and energetic performance, as well as the materials' variety. It is essential that a restoration/reconstruction project elaborates the traditional technologies, to efficiently adopt materials and functions. In such a way, an adequate combination of tradition and innovation could be reached, with the aim to apply the most efficient work in respect of the history of the building.

\section{REFERENCE}

[1] Campisi, T. \& Saeli, M., Constructive characters of the Western Sicilian masonry in the XVIII and XIX centuries. Proceedings of 6th REHABEND 2016 - Euro-American Congress, pp. 1237-1244, 2016.

[2] Campisi, T. \& Saeli, M., Aristocratic palaces in the XVIII century in Palermo. The construction site of Merendino-Costantino Palace. Proceedings of the 5th International Congress on Construction History (ICCH5), Vol. 1, pp. 333-340, 2015.

[3] Campisi, T. \& Mutolo, S., La protezione sismica nel cantiere palermitano del XVIII secolo: sistemi preventivi e di ricostruzione. Il caso delle cupole e dei soffitti voltati in legno e canne. Proceedings of the Conference "Norme per l'edilizia storica diffusa. Quale spazio per la tutela?", 2001.

[4] Campisi, T. \& Fatta, G., "I terribili tremuoti" nel XVIII secolo a Palermo. Dai danni alle nuove esperienze costruttive. Proceedings of the Congress Ar.Tec., pp. 19-33, 2009.

[5] Campisi, T. \& Mutolo, S., Palermo pietra su pietra. Apparecchi murari dell'edilizia settecentesca, Ila Palma: Palermo, 2003.

[6] Giuffrè, A. \& Carocci, C., Codice di pratica per la sicurezza e la conservazione del centro storico di Palermo, Laterza: Bari, 1999. 
[7] Vitruvio De architectura, II, 8, 20.

[8] Pliny the Elder., Rackham, H., Jones, W.H.S., Naturalis Historia. Harvard University: Cambridge, Mass. XXXV, 48, 1963.

[9] Palladio, A., The Four Books of Architecture, Dover Publications, Inc., New york: USA. Vol. I, XIX, p. 2, 1570.

[10] Bacchetta, A., Edilizia rurale romana, All'insegna del Giglio: Milano, 2003.

[11] Giovannoni, G., La tecnica delle costruzioni presso i Romani, Bardi: Roma, 1925.

[12] Adam, J.P., La construction romaine, matériaux et techniques, Picard: Paris, 1984.

[13] Tobriner, S., La casa baraccata: un sistema antisismico nella Calabria del XVIII secolo, Costruire in laterizio, 56, pp. 110-115, 1997.

[14] Battistini, B., Strutture in legno in zona sismica, Dissertation for the Degree in Civil Engineering, University of Bologna, academic year 2009/10.

[15] Ruggieri, N., Il sistema antisismico borbonico muratura con intelaiatura lignea genesi e sviluppo in Calabria alla fine del '700. Bollettino degli Ingegneri, 10, pp. 1-14, 2013.

[16] Vivenzio, G., Istoria e teoria de' tremuoti in generale: ed in particolare di quelli della Calabria e di Messina del MDCCLXXXXIII, Stamperia Reale: Napoli, 1783.

[17] Pesso, L., Sul consolidamento delle fabbriche nelle Calabrie contro i danni da terremoto, L'ingegneria civile e le arti industriali, Torino, 1876.

[18] Campisi, T. \& Scibilia, F., The Use of Wood with an Anti-seismic function in the architecture of Palermo during the 18th Century. In: H. Cruz, J. Saporiti Machado, A. Campos Costa, P. Xavier Candeias, N. Ruggieri \& J. Manuel Catarino (eds.), Historical Earthquake-Resistant Timber Framing in the Mediterranean Area, Lecture Notes in Civil Engineering, Springer International Publishing: Switzerland, pp. 113-124, 2016.

[19] Campisi, T., I soffitti in legno e canne nella tradizione costruttiva palermitana del XVII e XVIII secolo. Recupero \& Conservazione, 41, pp. 38-44 \& 42, pp. 62-66, 2001.

[20] Campisi, T., Wooden domes, vaulted and flat ceilings, partition walls in the Sicilian constructive tradition. Knowledge for the safeguard of architecture and technic. Proceedings of the 6th International Congress "science and technology for the safeguard of cultural heritage in the Mediterranean Basin”, vol. I, pp. 78-85, 2013.

[21] França, J.A., A reconstrução de Lisboa e a arquitectura pombalina, Biblioteca Breve: Amadora, 1989.

[22] Various authors, Manual of practice, Vol. I-II. Construction specifications Institute: Alexandria, Virginia, 1980.

[23] Lopes, V., Descriçao do sistema construtivo Pombalino, Dissertation for the Degree in Architecture, Universidade Técnica de Lisboa, Lisboa, 1999.

[24] Segurado, J.E., Trabalhos de carpintaria civil, Biblioteca de Instução Professional, Livraria Bertrand: Lisboa, w.d.

[25] Günay, R., The Tradition of the Turkish House and Safranbolu Houses, Endüstri Merkezi Yayınları, 1998.

[26] Aktaş, Y.D., Seismic resistance of traditional timber-frame hımış structures in Turkey: a brief overview. International Wood Products Journal, 1-8, 2017.

[27] Langenbach, R., From "Opus Craticium" to the "Chicago Frame": earthquakeresistant traditional construction. International Journal of Architectural Heritage, 1, pp. 29-59, 2007.

[28] Langenbach, R., What we can learn from traditional construction in seismic areas, available at www.conservationtech.com/IstanCon/keynote.htm

[29] Langenbach, R., Learning from the past to protect the future: armature crosswalls. Engineering Structures, 30(8), pp. 2096-2100, 2008. 